\title{
THE IMPORTANCE OF FESTIVAL TOURISM IN THE ECONOMIC DEVELOPMENT OF HUNGARY
}

\author{
Adrienn NAGY, Henrietta NAGY
}

Szent István University, Gödöllő, Hungary

Tourism has been a determining factor in the economic growth of Hungary recently and it will continue to have a significant role in the future development of the country. Although Hungary has great potentials in tourism sector, it is concentrated only on a few places of the country at present, especially in the capital, Budapest. While tourism has about 10\% share in the national GDP production, most of it is generated in the capital. In addition, to the center of the country, there are only a few places that are really known by foreign tourists and thus are able to attract crowds. Such places are Lake Balaton, the largest lake in Europe; and the city of Debrecen, the second largest city in the country, with its surroundings and several thermal baths. The aim of our paper is to analyze the tendencies of Hungarian tourism, focusing on the festivals, and to follow the changes of the tourism strategies, as well as the direct and indirect effects of the development of the tourism industry on the economic growth of the country. In order to prepare our study, we have collected information on tourism from the Central Statistical Office, from the organizers of the different festivals throughout the country and from the National Tourism Office. Based on our research, we intend to draw consequences on the sector and define recommendations for further developments, because we believe that festivals can be the solution for the sustainable economic and social development of several rural areas, providing income for a huge part of population in the countryside.

Keywords: tourism, youth, festivals, tourism development strategy

\section{Introduction}

In the center of Europe, lying in the Carpathian basin, Hungary has various geographic, natural and cultural potentials for tourism, but there are still unexploited capacities. One of the most significant natural endowments is thermal water. However, in addition to thermal tourism, Hungary has paid a lot of attention to elaboration of various initiatives, cultural programs, and incentives to increase the number of attractions recently. In order to moderate the seasonal effects of thermal and wellness tourism of summer and to make the tourism season all year long, it is inevitable to introduce new programs, to apply new marketing strategy and to expand the target group of tourism. Due to such factors, Hungary has been an important and popular player regarding festivals even in Europe. Thousands of European young people like visiting the Hungarian cultural and music events, festivals in different points of the country. One of the largest cultural festivals in Europe, called Sziget Festival, has been attracting increasing number of people from different parts of the continent in the past decade. In addition, there have been new festivals emerging in other Western and Eastern cities of the country, contributing to the economic development of those regions. The incomes generated related to such events can have short- and long-term impacts on those areas, offsetting the decisive role of Budapest.

One of the largest sectors that generate the highest income worldwide is tourism. However, it has a role not only in the economic life, but it plays increasing role in the life of individuals living in countries with a certain level of economic and social development. Tourism is an important part of the way of living and is also the way of expressing the changing lifestyle. Tourism has become a kind of industry in Hungary in the past decade that should be continuously developed in order to meet the expectations. In the case of Hungarian tourism, in the tight competition, it is not enough to concentrate on one field or to show the existing architecture and cultural treasures anymore. There is an increasing interest in the cultural events and programs that could bring the country and the tourists closer to each other more efficiently. In Hungary, the tourists prefer individual, special experience that is characteristic for the country (Lele, 2008).
The mission of the Hungarian Tourism PIc. (Magyar Turizmus Zrt.) is to contribute to taking the domestic touristic supply onto the market, thus facilitating the increase of income generated in tourism sector. This company is a national touristic organization, owned by the Hungarian Development Bank (Magyar Fejlesztési Bank), which was established on $1^{\text {st }}$ March 1994. With its activity, it supports the creation and maintenance of jobs, contributes to the balanced increase of the GDP and has positive impact on the current account of the country.

\section{Material and methods}

In our research we collected some of the data from the above mentioned company. In addition, we used official statistical data provided by the Central Statistical Office. In the paper we also write about a survey which was carried out to examine the significance of festivals in Hungary.

According to the data, the direct touristic sector produced $5.9 \%$ of the national GDP in 2008, while it produced 10\% indirectly. According to forecasts, tourism is expected to produce 7.1\% of the GDP directly by 2015 (CSO, 2009). According to the Act No 4/2000 (II.2.), there have been 9 touristic regions in Hungary since 2 February 2000 as follows: Budapest- Middle-Danube Region, Balaton Lake Region, West Transdanubia Region, Middle Transdanubia Region, South Transdanubia Region, North Hungary Region, North Great Plain Region, South Great Plain Region, Tisza Lake Region. Let us mention though, that the touristic regions do not always match the public administration borders of the counties. Therefore, these regions are not public administration units; they only make it easier to deal with the statistical data.

Considering the tendencies of the Hungarian tourism sector, an increasing competition could be observed by 2005. The single market, the ever-changing consumer demands as well as the appearance of new trends and forms of travelling required the development of tourism that is comprehensive, along with defined objectives and existing for long terms, over government cycles. Based on all this, Hungary needed a national tourism development strategy which includes the major priorities for the period 2005-2013 (NTS, 2005). The main objective of the strategy is to improve the quality of life through the development of tourism. 
"Festival is an event, whose aim is to provide joint entertaining or leisure-time experience of high quality for the audience, focusing on one or more topics, being organized regularly at one or more scenes, with cultural, art, gastronomical, sport or other programs (Hungarian Festival Association, 2009)". Similarly to the international trends, the festivals are more and more popular in Hungary. The events and festivals that focus on one topic are common in Hungary, and their success is reflected in the increasing interest of people. Our country is rich in festivals and events, since there is at least one musical, gastronomical or cultural event organized throughout the country each day of the year. Exhibitions, art events, gastronomic fairs, sport events and music programs are common. The latter is the most important at national and international level, since many young people visit e.g. the Sziget Festival and the VOLT Festival each year (Lele, 2008).

Today's festival tourism is fundamentally influenced by the traditions of festival visits formed in the last 1.5-2 decades. It is difficult not to get lost in the list of festivals, since one festival is followed by another, especially in the summer period. The Hungarian Tourism PIc. defined the festivals as a pillar of the Year of Cultural Tourism in 2009, and festivals were the topic of the incoming tourism in 2010 (Turizmus Bulletin, 2009). Festivals can be put into different categories based on various factors. According to their duration, we can distinguish one-day festivals, festivals of several days, one-week or even several month-long festivals. According to the attraction zone of the festivals, local, regional, national and international ones can be distinguished. Tourism experts say that the events that are accompanied by a travel of minimum $60 \mathrm{kms}$ and minimum one night stay are important from touristic point of view. The frequency of organizing is also important: there are single and periodical events. The latter can have significant brand-development impacts and even a jubilee event can be organized consciously as quasi being the first element of a series (Getz, 1991).

The festival tourism got significant priority in the Cultural Tourism Strategy of the Ministry of Education and Culture as well, which is planned for the period 2006-2010 (0KM, 2007). The strategy primarily focuses on the important cultural events (Cultural Capital of Europe, Hungarian Town of Culture and other important exhibitions and international seasons), while several festivals were supported by the Ministry of Municipalities in the frame of National Cultural Fund. One of the bottlenecks of the sustainability of festivals is public financing. The acknowledgement of festivals is reflected by the fact that the ministries concerned supported the events with several billions of forints (40 events received HUF 300 million in 2007, while 45 events received HUF 400 million in 2008 (Mányai, 2009). Moreover, smaller events could get HUF 800 million through regional projects in 2008. In 2009, the joint project fund was HUF 700 million, from which 63 events could receive support. From the project finances, HUF 100 million was available for gastronomic events with cultural purposes. Festival tourism is also included in the accentuated touristic investments of the New Hungary Development Plan: the festival venue in Tokaj received support of more than HUF 2 billion (Mányai, 2009).

\section{Results and discussion}

According to the Travel \& Tourism Competitiveness Index (TTCl), European countries are dominant within the most competitive ones from touristic aspects. On the touristic competitiveness rank, as much as 139 countries were listed in 2011, while in 2009, there were 133. Total of 7 countries out of the best 10 and 14 out of the best 20 were European. Hungary is on the $38^{\text {th }}$ place as in 2009 (Turizmus Panoráma Bulletin, 2011).

After our EU accession, the number of foreign tourists visiting Hungary started to increase gradually. Nearly 34 million people visited Hungary in
2004, which increased to almost 41 million by 2009. However, there was a decrease in 2010, which is not in direct correlation with the expenditures. The expenditures of foreigners visiting Hungary has been increasing recently (except for the year 2007). By 2010, they exceeded HUF 671 billion. The number of people visiting festivals has increased significantly recently and the judgment of domestic festival supply has also improved. At present, there are 3,000 domestic festivals registered. At the moment, about onethird of the Hungarian population is "festival-fan". The most popular ones are the gastronomic and pop music festivals. Most of the Hungarian people (9 out of 10) know at least one Hungarian festival. As much as $68.5 \%$ of the Hungarians planned visiting festivals in the Year of Festivals. Total of $65.1 \%$ of the Hungarians took part in at least one festival between January 2007 and March 2010.

Sziget Festival is one of the largest cultural and pop music festivals in Europe, taking place in August on the Óbuda-island in Budapest. The history of the festival goes back to 1993, when a program called Diáksziget was organized with a motto "We need one week together". The festival took place under the name Pepsi Sziget from 1996 to 2001. It was named Sziget Festival in 2002. Alternative and rock music was determining earlier, but in 2000 it became a festival of all genres. It is about leaving your everyday life- one-week partying, concerts, having fun. In the temporary festival city, several services are available for the visitors: post office, bank, pubs, restaurants, shops. On the "thematic" stages, in addition to the most popular pop music, you can non-stop listen to hard rock, world music, electric dance music, alternative style, blues and jazz as well,. The visitors can also watch theatre plays and modern dance, exhibitions, literature, classical concerts, opera-, circus and other performances. Furthermore, sport programs are also offered by the organizers and civil organizations inform the youth about various topics. The financial success of the festival is partly due to the increase in the number of performers and also to other festivals organized by the same company. This company is responsible for organizing the successful VOLT Festival, the Balaton Sound electric dance music festival and the Day of Passion for the addicted people.

VOLT Festival is one of the largest pop music festivals of Hungary, taking place in Sopron each year since 1993. The festival is named after a popcultural magazine titled VOLT existing at the beginning of the 90s. The event features various music types ranging from rock, electric, world music and jazz to others. At the beginning (1993-2001), the festival took place in the Sport center of Sopron around the time of Easter, with increasing number of performers and visitors. Due to the increased popularity, both the permanent venue and date of the festival changed in 2002, becoming a summer festival. The event has gained international acknowledgement, since the number of well-known foreign performers has been increasing and as well as the share of the audience from abroad (primarily from Western and Eastern European countries) (Wikipedia, 2011).

Budapest Parade, called as the Hungarian Loveparade, is one of the largest free, open-air demonstrations of Budapest and Hungary, which was organized in 2000 for the first time by the Sziget Production Company. Since that time, the parade has been one of the most significant music and cultural events of Budapest, taking place on the last Saturday of August.

EFOTT (the National Touristic Meeting of the University and College Students) has the longest history among the summer festivals. The first was organized in 1976, where 350 students from 25 colleges and universities got together. In 2010, the number of visitors was 64,000 ! The specialty of the festival is that it is organized in different parts of the country year by year. At this festival, the most popular Hungarian bands perform, but there are other cultural, sport and touristic programs available as well (www.efott.hu). 


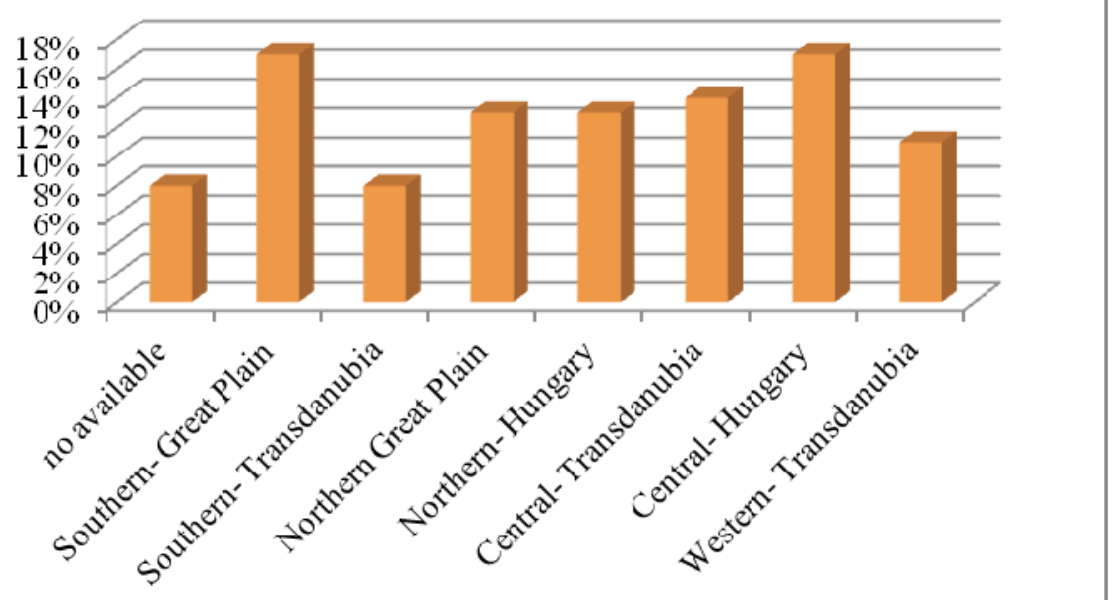

Figure 1 Regional distribution of registered festivals in \% Source: Registration and Qualification Program of Hungarian Festivals, own editing, 2011

In 2009, 54.7\% of Hungarians visited festivals. One festival-visitor participated in 2.2 festivals on average. The most popular destination was the Lake Balaton Region (15.2\%), which was followed by Northern Great Plain (14.7\%) and Budapest-Middle-Danube Region (13.3\%). Twothirds of the festival visits lasted for 1 day, $27.1 \%$ for 1-3 nights and longer stays were represented by $8.3 \%$. During festival visits for more than one day, the travelers usually spend 2.8 nights on average (MT Zrt., 2009). As for the regional distribution of the 212 festivals registered on the website of the Registration and Qualification Program of the Hungarian Festivals, we can see that $17 \%$ take places in the Central-Hungary region and another $17 \%$ in the Southern Great Plain. The fewest festivals are organized in the Southern Transdanubia region.

\section{Conclusions}

The year 2010, being the "Year of Festivals", greatly contributed to the increase of popularity of such events. Regarding the festivals, the Sziget Festival, the Budapest Parade, the VOLT and the Balaton Sound are of great importance. As it is characteristic to the Hungarian tourism sector, the festival tourism also shows territorial concentration. The venue of the two most popular festivals is Budapest, which is followed by the festival near Lake Balaton. Territorial concentration goes along with high rate of seasonality, which makes it more difficult to realize similar events. The demand for such programs usually occurs in spring or summer, since most of them take place open air. We believe that it would be very important to establish a good marketing activity for the festivals, because most of the tourists take part in such festival because they are staying in that city at that moment, but not because the advertisement of the festival attracted them to the place. Festival tourism may have significant advantages, but the touristic destinations should avoid the over-supply of these events. At present, there are around 3,000 festivals registered in Hungary, out of which only 400-500 have real significance. The reason for this is that series of concerts or other cultural programs (e.g. theatre plays) are also called festivals. A very important task would be linking the programs to each other, supplementing the existing supply, coordinating the events paying attention to their dates. Hungary (due to its endowments) allows several wine festivals throughout the country in a certain period of the year, but they are very similar to each other, only their venues are different. Instead of compressing them into a short period, we should rather create a series of programs for the whole year. The festivals in the series should complement each other instead of competing with each other, resulting in a balanced supply for the people interested throughout the year.

As it can be seen based on the above mentioned, the festivals have been increasingly popular among young people; thus, both from cultural and financial aspects, they can be considered successful and good investments. Therefore, they represent a very good possibility for the development of the sector that may result in increasing incomes for the Hungarian entrepreneurs and increasing popularity for the whole country. Festivals are expected to continue their development and contribute to the profitability of the Hungarian tourism industry.

\section{References}

CENTRAL Statistical Office. 2009. Report about the performance of tourism in 2009, on-line publication, Budapest

GETZ, D. 1991. Festivals, Special Events and Tourism, Van Nostrand Reinhold, New York.

HUNGARIAN Tourism Plc. surveys

HUNGARIAN Festival Association. 2008. General meeting and conference, Pécs

HUNYADI, Zs et al. 2006. Festival world, Kultúrpont Office

KÁPOSZTA, J. - NAGY, H. - VILLÁNYI, L. 2008. Enlargement processes in the European Union and the sustainability indicators of Bulgaria and Romania, In: Szücs István, Zsarnóczai J Sándor, Molnár József, Benet Iván, Szabó Gábor, Szabó Lajos, Villányi László, Hajós László, Lehota József, Farkasné Fekete Mária, Kanizsay Endre, Khaled Karim, Mrs Mária Kadlecíková, Magdalena Hrabankova, Alvaro Standardi, Francis Nwonwu, Carlos Noéme (szerk.), Economics of Sustainable Agriculture I-II.: Scientific Book Series, Gödöllő : Szent István University, 2008. pp. 79-103. ISBN 978-963-269-016-2; 9639483699

LELE, D. 2008. The impacts of conference and festival tourism on the improvement of Hungary's image. Budapest: Economic College, 2008.

MÁNYAI, R. 2009. The role of culture in the development of tourism. The future of Europe - the culture of the future, international cultural-touristic conference, 2009.

NATIONAL Tourism Development Strategy. 2005. Budapest SURVEYS carried out by NRC Market Research Company.

SMITH, M. 2009. An International Overview of Festival Tourism. In: Tourism Bulletin, 2009

THE CULTURAL Tourism Strategy of the Ministry of Education and Culture 2006-2010

TOURISM Panorama Bulletin, 24 March 2011

\section{Contact address:}

Adrienn Nagy, PhD student, 2100, Gödöllő, 1 Páter K. str., Phone: +36 28522 000/2372, e-mail: nagy.adrienn@gtk.szie.hu 